\title{
Characteristics of GLP-1 and exendins action upon glucose transport and metabolism in type 2 diabetic rat skeletal muscle
}

\author{
LUIS ARNÉS, NIEVES GONZÁLEZ, PILAR TORNERO-ESTEBAN, VERÓNICA SANCHO, ALICIA ACITORES, \\ ISABEL VALVERDE, ELENA DELGADO and MARÍA L. VILLANUEVA-PEÑACARRILLO
}

Department of Metabolism, Nutrition and Hormones, Fundación Jiménez Díaz, Avda. Reyes Católicos 2, E-28040 Madrid, Spain

Received February 28, 2008; Accepted April 14, 2008

\begin{abstract}
Exendin-4, a peptide 53\% structurally homologous with glucagon-like peptide 1 (GLP-1), is insulinotropic and has an antidiabetic effect even more prolonged than that of GLP-1. Exendin-9 is an antagonist of GLP-1 receptor and action in several cell systems, but shows GLP-1- and exendin-4agonistic characteristics in human muscle cells and tissue. The action of GLP-1 upon glucose transport and metabolism in muscle is mediated by specific receptors. In this study we investigated the effect of both exendin- 4 and -9 , relative to that of GLP-1, upon glucose transport and metabolism in the skeletal muscle from a streptozotocin-induced type 2 diabetic rat model, compared to normal. In normal rats, exendin-4, like GLP-1 and insulin, enhanced glucose uptake. This effect, which is mediated to a certain extent by some kinases (PI3K/ PKB, p70s6k and MAPKs), may be caused by the peptide acting, at least in part, through the muscle GLP-1 receptors. Exendin-9 also stimulated the same kinases, except for PKB, but failed to modify basal glucose uptake. Type 2 diabetic rats showed lower than normal basal muscle glucose transport and oxidation value, and higher glycogen synthase $a$ activity and pyruvate release; however, no modification of glucose uptake by GLP-1 or exendin-4 was detected, at variance with insulin, and basal activity of PI3K/PKB was lower than normal, while that of p70s6k and MAPKs was higher. GLP-1 failed to affect the activity of any of the kinases, while exendin-4 increased the activity of PI3K, p70s6k and MAPKs, but not $\mathrm{PKB}$, suggesting that this enzyme plays a major role in exendin-4 effect upon glucose transport in muscle.
\end{abstract}

\section{Introduction}

Exendin(1-39)amide (Ex-4), a peptide of non-mammalian nature that shares $53 \%$ structural homology with glucagon-like peptide 1 (GLP-1), is under current investigation because of

Correspondence to: Dr M.L. Villanueva-Peñacarrillo, Department of Metabolism, Nutrition and Hormones, Fundación Jiménez Díaz, Avda. Reyes Católicos 2, E-28040 Madrid, Spain

E-mail: mlvillanueva@fjd.es

Key words: exendins, glucagon-like peptide-1, skeletal muscle, glucose metabolism, diabetic rat its antidiabetic effect. The in vivo action of Ex-4 is even more prolonged than that of GLP-1, perhaps due to its lack of susceptibility to enzymatic degradation by dipeptidyl peptidase IV (1-3), a characteristic that confers more stable properties on the peptide when in circulation. Ex-4, like GLP-1, is insulinotropic (4), and has GLP-1- and insulin-like effects on parameters related to glucose or lipid metabolism in extrapancreatic tissues. Ex-4 increases glucose transport in rat adipocytes (5) and human myocytes (6), and glycogen synthase $a$ activity in rat liver and rat and human muscle $(7,8)$, and stimulates lipogenesis and lipolysis in rat fat tissue (5). The reported extrapancreatic effects of Ex-4 seem to be dependent on certain kinases, some of which also participate in GLP-1 action $(5,6)$.

Despite the fact that Ex-4 mimics GLP-1 in some of its effects, attempts to identify receptors for Ex-4 in human or rat pancreas or other tissues have so far failed. However, it is known that GLP-1 specifically binds to the plasma membranes of major extrapancreatic tissues participating in glucose homeostasis and lipid metabolism, indicating the presence of receptors which, in liver and muscle at least, seem to be structurally or functionally different (8-11) from that in the pancreas (12).

The Ex-4 truncated form, exendin(9-39)amide (Ex-9), is an antagonist of GLP-1 receptor in several cell systems $(3,13)$ and of its insulinotropic effects in rat pancreas (14), and of GLP-1 action upon glucose metabolism in rat liver cells and muscle tissue (7); however, in adipocyte (15) and myocyte (16) cell lines, and in normal human muscle $(6,8)$, Ex-9 acts as an agonist of GLP-1 action.

It has been shown that the increasing effect of GLP-1 upon glycogen synthase $a$ activity and glycogen synthesis in normal rat skeletal muscle is maintained in a type 2 diabetic model (17). Moreover, a lack of Ex-9 effect upon the activity of rat adipocyte $\mathrm{PKB}$ signalling enzyme, which is reversed in type 2 diabetic states, has recently been reported (5).

The aim of this study was to explore the characteristics of Ex-4 and also Ex-9 effect, relative to that of GLP-1, upon glucose transport and metabolism in the skeletal muscle of normal and type 2 diabetic rats.

\section{Materials and methods}

Reagents. Human GLP-1(7-36)amide (GLP-1, Bachem AG, Bubendorf, Switzerland); pork insulin (Novo Biolabs, Bagsvaerd, Denmark); exendin(1-39)amide (Ex-4) and 
exendin(9-39)amide (Ex-9) (gifts from Dr John Eng, VAMC, NY, USA); adenosine triphosphate (ATP); $\left[\gamma^{32} \mathrm{P}\right]-\mathrm{ATP}$ $(30 \mathrm{Ci} / \mathrm{nmol})$, horseradish peroxidase-conjugated donkey anti-rabbit immunoglobulin, Rainbow markers, D-[U- $\left.{ }^{14} \mathrm{C}\right]$ glucose $(300 \mathrm{mCi} / \mathrm{mmol})$, ECL-Western blotting kit and Hyperfilm ECL, (Amersham Pharmacia Biotech, Buckinghamshire, UK); rapamycin (RAP), wortmannin (W), H-7, phosphatidylinositol and phosphatidylserine, Resin Dowex 1X8-400 (Sigma Aldrich Quimica S.A., Madrid, Spain); PD98059 (PD) (Calbiochem ${ }^{\circledR}$, La Jolla, CA, USA); rabbit anti-total and antiphosphorylated form of p44/42MAP kinase, p70s6k and PKB (Cell Signalling Technology, New England Biolabs, Beverly, MA, USA); rabbit anti-PI3-kinase p85 (Upstate Biotechnology, Lake Placid, NY, USA); 2-deoxy-D-[1,2- $\left.{ }^{3} \mathrm{H}(\mathrm{N})\right]$ glucose (40 Ci/mmol, Moravek Biochemicals, Brea, CA, USA); $\left[\mathrm{U}-{ }^{14} \mathrm{C}\right]$ sorbitol $(320 \mathrm{mCi} / \mathrm{mmol}$, American Radiolabeled Chemicals, Inc., St. Louis, MO, USA); Ultima Gold scintillation liquid (Packard, Gröninger, The Netherlands). All other commonly used chemicals were from Sigma or Merck (Merck Pharma Quimica, S.A., Barcelona, Spain). Normal Wistar rats, fed on a standard pellet diet (UAR Panlab, Barcelona, Spain), were obtained from the animal breading station of the Fundación Jiménez Díaz.

Experimental animals. Male Wistar rats, kept on a standard pellet diet and tap water ad libitum, were used. Rats were rendered diabetic by a single dose of streptozotocin (STZ, $100 \mu \mathrm{g} / \mathrm{g}$ body wt) dissolved in $25 \mu \mathrm{l}$ of $0.05 \mathrm{M} \mathrm{Na}$ citrate, $\mathrm{pH} 4.5$, intraperitoneally administered on the day of birth (18). At the age of 6-7 weeks, those animals showing a glucose disappearance constant $(\mathrm{K})$ below $2.5 \times 10^{-2} \mathrm{~min}^{-1}$ during an i.v. glucose tolerance test $(0.5 \mathrm{mg}$ glucose $/ \mathrm{g}$ of body wt, in $30 \mathrm{sec}$ ) were selected (19). A total of $104 \mathrm{STZ}$ induced type- 2 diabetic rats (T2D rats) were used in this study. Their body weight and $\mathrm{K}$ value averaged $231.8 \pm 3.2 \mathrm{~g}$ and $1.32 \pm 0.04 \times 10^{-2} \mathrm{~min}^{-1}$, respectively. Normal rats $(\mathrm{n}=189)$ were also studied. Animal housing and protocols were approved by the Animal Use Committee of the Fundación Jiménez Díaz, Madrid, Spain.

Binding. We studied the displacement by Ex-4 and Ex-9, of the radiolabeled GLP-1 binding to rat muscle membranes, which was performed at $25^{\circ} \mathrm{C}$ over 40 min as previously described in detail (11).

Glucose transport. Rats were sacrificed by decapitation, and the soleus muscles were removed and individually attached by the tendon to a steel clip (20). Paired soleus muscles were preincubated during $15 \mathrm{~min}$ at $37^{\circ} \mathrm{C}$, in $3 \mathrm{ml} \mathrm{Krebs-Henseleit}$ buffer $(\mathrm{KH})$ without or with $2.5 \times 10^{-5} \mathrm{M}$ PD (MEK inhibitor), $10^{-6} \mathrm{M} \mathrm{W}$ (PI3K inhibitor), $10^{-7} \mathrm{M}$ RAP (p70S6k inhibitor) or $10^{-4} \mathrm{M} \mathrm{H}-7$ (PKC inhibitor), followed by a 30-min incubation in the absence (basal) and presence of each exendin or GLP-1. This was followed by a 60 -min incubation in the additional presence of $15 \mu \mathrm{mol} 2$-deoxy-D-[1,2- $\left.{ }^{3} \mathrm{H}(\mathrm{N})\right]$ glucose (Sp. Act: $40 \mathrm{nCi} / \mu \mathrm{mol})$ and $60 \mu \mathrm{mol}\left[\mathrm{U}-{ }^{14} \mathrm{C}\right]$ sorbitol (Sp. Act: $5 \mathrm{nCi} / \mu \mathrm{mol}$ ), 5 and $20 \mathrm{mM}$, respectively, in the incubation media. In another group of experiments, paired muscle samples were treated as above, but in the absence of added peptide and presence or absence of the inhibitor. During the preincubation and incubation periods, an atmosphere of $\mathrm{O}_{2} / \mathrm{CO}_{2}(95 / 5)$ was maintained in the vials sealed with a rubber stopper. After incubation, extracellular radioactivity was removed by quickly washing at $4^{\circ} \mathrm{C}$ in $\mathrm{KH}$, and the muscle was treated with $1 \mathrm{ml} 1 \mathrm{~N} \mathrm{NaOH}$ for $10 \mathrm{~min}$ at $70^{\circ} \mathrm{C}$ and placed in $5 \mathrm{ml}$ scintillation liquid for ${ }^{3} \mathrm{H}$ and ${ }^{14} \mathrm{C}$ content determination by double-channel counting; an aliquot volume $(2 \mu \mathrm{l})$ had previously been taken from all solubilized samples for the measurement of total protein (21).

To calculate the cellular D-glucose uptake in each muscle sample (pmol/min per mg protein), the total 2-deoxy-D-[1,2$\left.{ }^{3} \mathrm{H}\right]$ glucose accumulated was corrected taking into account the extracellular space, as determined by the $\left[{ }^{14} \mathrm{C}\right]$ sorbitol uptake value, following a method previously described (22).

Glycogen synthase $a$. Rats were sacrificed by decapitation, and the soleus muscles were removed and individually attached by the tendon to a steel clip. For glycogen synthase $a$ activity studies (17), the muscles were preincubated for $60 \mathrm{~min}$ at $37^{\circ} \mathrm{C}$ in $1.5 \mathrm{ml} \mathrm{Krebs-Ringer} \mathrm{bicarbonate} \mathrm{(KRB)} \mathrm{buffer}$ containing $1 \%$ BSA and $5 \mathrm{mM}$ D-glucose. This was followed by a 10 -min incubation at $37^{\circ} \mathrm{C}$ in the same medium as above, in the absence (basal) and presence of $10^{-9} \mathrm{M} \mathrm{Ex}-4$, as this concentration has previously been shown to exert maximal effect upon normal muscle glucose metabolism in vitro $(8,20)$. During preincubation and incubation, an atmosphere of $\mathrm{O}_{2} / \mathrm{CO}_{2}(95 / 5)$ was maintained in the vial sealed with a rubber stopper. One of the muscles from each rat was always incubated in the absence of peptides for paired basal. The tissue samples were immediately homogenized in a medium containing $100 \mathrm{mM} \mathrm{NaF}, 35 \mathrm{mM}$ EDTA and $0.5 \%$ glycogen (w/v) at $\mathrm{pH} 7.4$, as already described (20), and maintained at $-70^{\circ} \mathrm{C}$ until the enzymatic activity was assayed.

The frozen tissue homogenates were thawed at $4^{\circ} \mathrm{C}$ and their enzymatic activity was assayed, at least in duplicate, as the incorporation of UDP-glucose into glycogen, over a 15-min period, as previously described in detail (20). In each experimental rat, the mean value of the replicates corresponding to the muscle incubated in the absence of Ex-4 was used as basal value.

Kinase activity. In another group of experiments, designed to study MAPK, PI3K, PKB or p70s6k enzyme activity, muscles were preincubated for $60 \mathrm{~min}$ in $\mathrm{KRB}$ with $1 \%$ BSA and $5 \mathrm{mM}$ $\mathrm{D}$-glucose, followed by a 3-min incubation in the absence (basal, one per rat) or presence of either GLP-1, Ex-4, Ex-9 or insulin, after which, tissue samples were homogenized at $4^{\circ} \mathrm{C}$ in $1.25 \%$ Triton $\mathrm{X}-100$ containing $250 \mathrm{mM}$ sucrose, $20 \mathrm{mM}$ Tris/ $\mathrm{HCl}, 2.5 \mathrm{mM} \mathrm{MgCl} 2,50 \mathrm{mM} ß$-mercaptoethanol, $1.2 \mathrm{mM}$ EGTA, $1 \mathrm{mM} \mathrm{Na}_{3} \mathrm{VO}_{4}, 5 \mathrm{mM} \mathrm{Na}_{4} \mathrm{P}_{2} \mathrm{O}_{7}, 50 \mathrm{mM} \mathrm{NaF}$, $30 \mathrm{U} / \mathrm{ml}$ bacitracin, $2 \mu \mathrm{M}$ leupeptin, $2 \mu \mathrm{M}$ pepstatin, $\mathrm{pH} 7.4$, and $2 \mathrm{mM}$ PMSF, then maintained at $4^{\circ} \mathrm{C}$ for $30 \mathrm{~min}$, and finally centrifuged at $15,000 \mathrm{x} \mathrm{g}$ (23). The supernatant (tissue lysate), containing cytosol and solubilized membranes, was kept at $-70^{\circ} \mathrm{C}$ until needed.

An aliquot volume was taken from all tissue lysate samples for protein content determination (21).

Immunoblotting. Equal amounts of tissue lysate from each muscle sample were subjected to SDS-PAGE (24), in parallel 
with molecular weight markers, on an $8 \%$ resolving gel; the separated proteins were then transferred to a nitrocellulose membrane in a semidry system (Trans-Blot SD Semi-Dry Transfer Cell, Bio-Rad). For immunodetection, a Western blotting kit was used according to the manufacturer's instructions, using total and phosphorylated p44/42 MAPK, PKB and p70s6k respective antibodies, and a horseradish peroxidase-conjugated donkey anti-rabbit immunoglobulin second antibody, with detection by enhanced chemiluminescence and quantization by densitometric scanning of the autoradiography (25). In all experiments, the densitometric value of the band corresponding to the soleus muscle incubated in the absence of peptide was used as basal value.

PI3K activity. The enzyme activity was measured directly in p85 immunoprecipitates obtained by treating the muscle lysates with anti-PI3-kinase p85 and subsequent coupling to protein A-agarose (26). The immunoprecipitates were incubated for $20 \mathrm{~min}$ at room temperature with $20 \mu \mathrm{M}$ [ $\left.\gamma^{32} \mathrm{ATP}\right]$ (5 $\mu \mathrm{Ci} / \mathrm{nmol}$ ) containing $6.25 \mathrm{mM}$ Hepes, $5 \mathrm{mM} \mathrm{MgCl}$ and $0.25 \mathrm{mM}$ EGTA, and in the presence of $0.25 \mathrm{mg} / \mathrm{ml}$ phosphatidylinositol/phosphatidylserine as substrate; the reaction was interrupted by the addition of $400 \mu \mathrm{l}$ chloroform/methanol/ $\mathrm{HCl}(1: 2: 1, \mathrm{v} / \mathrm{v}), 150 \mu \mathrm{l}$ chloroform and $150 \mu \mathrm{l} \mathrm{HCl}$. After centrifugation $(10,000 \mathrm{xg})$, the organic phase was treated with an equal volume of methanol/100 mM HCl/2.5 mM EDTA $(1: 1: 1, \mathrm{v} / \mathrm{v})$, and the new organic phase was separated by centrifugation and speed-vac dried. The lipidic extract, redissolved in chloroform, was spotted, together with $\mathrm{PIP}_{3}$ standard, on a silicagel TLC plate, and developed in n-propanol/acetic acid/ $\mathrm{H}_{2} \mathrm{O}(66: 2: 33$, v/v). Plates were dried, and radioactive $\mathrm{PIP}_{3}$ was subsequently visualized by autoradiography and analyzed by densitometric scanning. In all experiments, the densitometric value of the band corresponding to the muscle incubated in the absence of each hormone/peptide, was used as basal value.

Glycolysis. Paired soleus muscles were incubated for $90 \mathrm{~min}$ without (basal) or with Ex-4. After that, the incubation medium was collected for pyruvate content determination by isolating the acidic metabolites by anion exchange chromatography (27). Simultaneously, $\mathrm{CO}_{2}$ was measured by the method already described in detail for human skeletal muscle strips (8).

Statistical study. Results are expressed as mean \pm SEM, together with the number of observations. The statistical significance $(\mathrm{p}<0.05)$ of the increments was assessed either by one-way analysis of variance, followed by the least significant difference (LSD) test for post hoc multiple comparisons, using the Statistical Package for Social Sciences (SPSS) software or the Student's $t$-test.

\section{Results}

GLP-1 binding displacement. The radiolabeled GLP-1-tracer maximal specific binding $(3.4 \pm 0.3 \%$ of total $)$ in $30 \mu \mathrm{g}$ membrane protein was displaced by increasing concentrations of unlabeled GLP-1, with a $50 \%$ inhibition dose $\left(\mathrm{ID}_{50}\right)$ close to $3 \times 10^{-9} \mathrm{M}$, as previously reported (11). Ex-4 competed with GLP-1 binding, with close to the same potency as that of GLP-1 $\left(\mathrm{ID}_{50}=10^{-8} \mathrm{M}\right)$; however although Ex-9 appeared to compete with the GLP-1 binding, its potency was much lower than that of GLP-1 or Ex-4 $\left(\mathrm{ID}_{50}=3 \times 10^{-7} \mathrm{M}\right)$.

Effect on kinase activity. In the skeletal muscle of normal rats (Fig. 1), both Ex-4 and Ex-9 increased the activity of PI3K, p70s6k and p44 and p42 MAP kinases (overall mean value: $154 \pm 6 \%$ basal, $n=24, p<0.001$ ), with respect to the basal value obtained in the absence of peptide, as previously detected with GLP-1 and insulin (28). Ex-4, like GLP-1, also stimulated PKB phosphorylation $(153 \pm 15 \%$ basal, $n=4$, $\mathrm{p}=0.034)$, while no effect by Ex-9 $(97 \pm 17 \%$ basal $)$ was observed.

In muscle samples from T2D rats (Fig. 2), basal PI3K and PKB activity was lower than those in normal rats (overall mean value: $77 \pm 6 \%$ normal, $n=8, p<0.01$ ), while that of MAPKs and p70s6k was higher (overall mean value: $204 \pm 19 \%$ normal, $\mathrm{n}=11, \mathrm{p}<0.001)$. A clear increase in MAPK and p70s6k activity by insulin (overall: $138 \pm 7 \%$ basal, $n=11$, $\mathrm{p}<0.001$ ) and Ex-4 (overall: $172 \pm 16 \%, \mathrm{n}=10, \mathrm{p}<0.01$ ) was detected, and also in PI3K activity by Ex-4 $(130 \pm 10 \%, \mathrm{n}=5$, $\mathrm{p}<0.05)$, but no effect of Ex-4 or insulin in PKB activity could be detected (overall: 100 $\pm 6 \%, n=15$ ). Ex-9 and GLP-1, both failed to affect the activity of any of the kinases, except for Ex-9 on p42 MAPK, for which a moderate stimulation was measured $(124 \pm 5 \%, \mathrm{p}<0.01, \mathrm{n}=5)$, similar to that in normal rat muscle $(142 \pm 11 \%, \mathrm{p}=0.01, \mathrm{n}=5)$.

Glucose transport. In normal rats the net 2-deoxy-D-glucose uptake in the absence of any peptide/hormone (basal), in muscle samples from 73 animals averaged $425 \pm 25 \mathrm{pmol} / \mathrm{mg}$ protein per $\min$. Ex-4, at $10^{-9} \mathrm{M}$, induced a clear stimulation (Fig. 3) of glucose transport, giving a value $(129 \pm 5 \%$ basal, $\mathrm{p}<0.002, \mathrm{n}=13$ ) similar in magnitude to that previously detected with a ten times higher concentration $\left(10^{-8} \mathrm{M}\right)$ of GLP-1 or $10^{-9} \mathrm{M}$ insulin (28). No further increment was measured when GLP-1 or Ex-4 were simultaneously present in the incubation medium (96 $\pm 8 \%$ GLP-1, n=7). Ex-9 did not modify the basal glucose uptake value $(92 \pm 5 \%$ basal, $n=14)$ or that stimulated by Ex-4 (104 $\pm 7 \% \mathrm{Ex}-4, \mathrm{n}=5)$.

The increasing effect of Ex-4 upon glucose uptake in the normal skeletal muscle (Table I) was reduced by W, a PI3K inhibitory agent, to a similar value to that obtained in the sole presence of the inhibitor, at variance with the reported partial lowering effect of $\mathrm{W}$ upon the stimulatory action of GLP-1. Inhibition of MAPK activity by PD, that of p70s6k by RAP or PKC by $\mathrm{H}-7$, abolished the increasing action of Ex-4 to a level (overall mean value: $75 \pm 4 \%$ basal, $n=28$ ) indistinguishable from that reached by the respective inhibitor alone (overall mean value: $84 \pm 7, n=18$ ), as it occurred with the action of GLP-1 (28) in the concomitant presence of each of the same inhibitory agents.

In $\mathrm{T} 2 \mathrm{D}$ rats, basal glucose transport value represented $345 \pm 16 \mathrm{pmol} / \mathrm{mg}$ protein per $\min , \mathrm{n}=47$, lower $(\mathrm{p}=0.027)$ than that in normal rats. Unlike insulin, by which a clear increase $(142 \pm 5 \%$ basal, $\mathrm{n}=11, \mathrm{p}<0.001)$, similar in magnitude to that exerted in normal rat muscle, was measured, no effect could be detected with GLP-1, Ex-4 or Ex-9 (overall mean value $101 \pm 5 \%, \mathrm{n}=34$ ). 


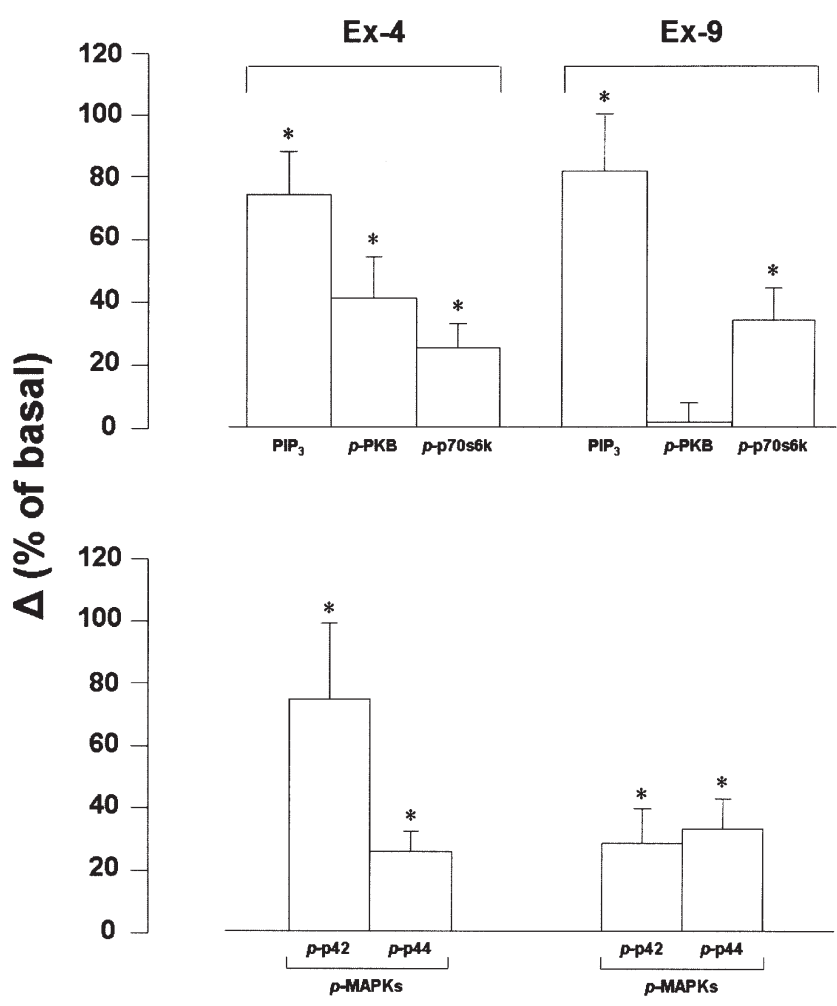

Figure 1. Effect of $10^{-9} \mathrm{M}$ Ex-4 and Ex-9 upon PI3K, p44/42 MAPK and p70s6k activity in the skeletal muscle (soleus) of normal rats. Values (mean \pm SEM) are expressed relative to the mean basal value found within the same rats $(n=3-5)$ and refer to $6-12$ separate determinations. ${ }^{*} \mathrm{p}<0.05$ vs basal.
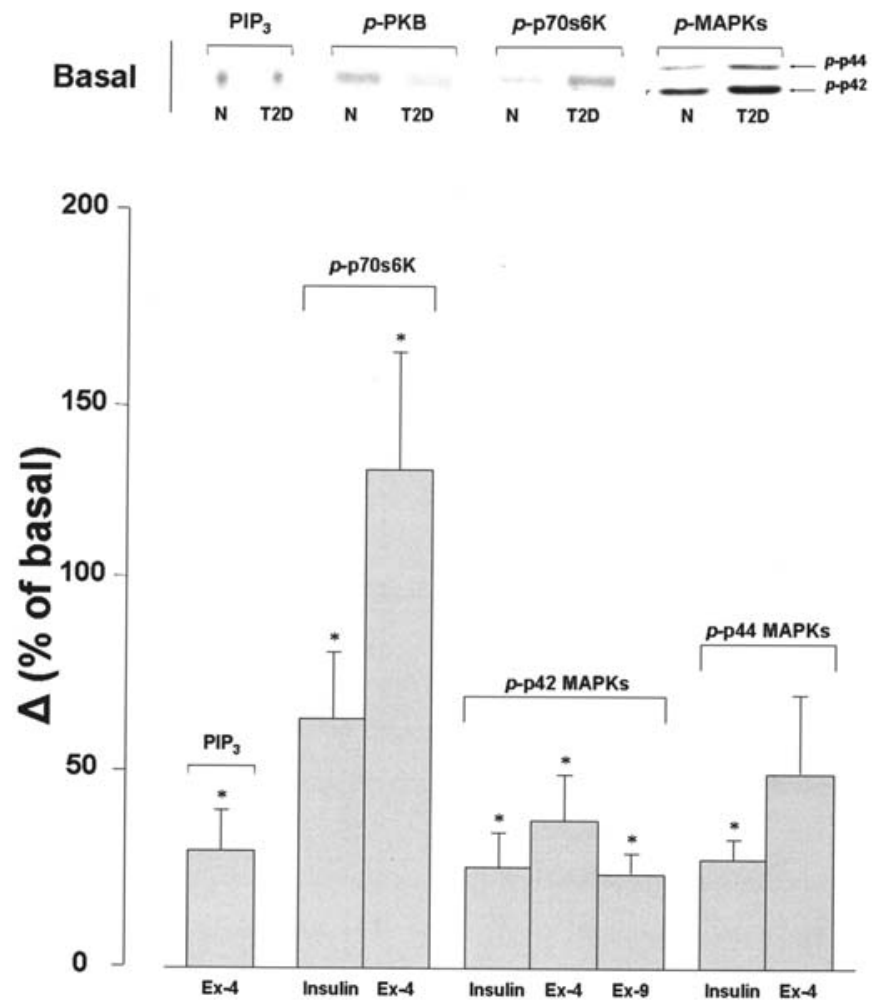

Figure 2. Effect of $10^{-9} \mathrm{M}$ Ex-4, Ex-9 and insulin upon PI3K, PKB, p70s6k and MAPK activity, in the skeletal muscle of streptozotocin-induced type 2 diabetic rats (T2D): representative inmunoblot of normal and T2D basal values, and percent increment (mean \pm SEM) of the basal value found within the same rats. ${ }^{*} \mathrm{p}<0.05$ vs basal.

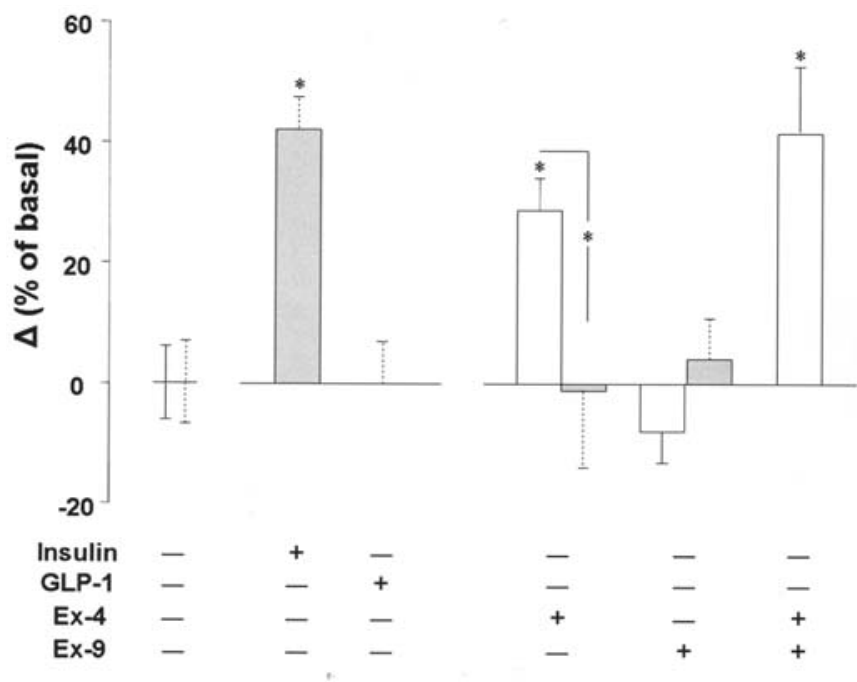

Figure 3. Effect of $10^{-9} \mathrm{M}$ Ex-4, Ex-9, GLP-1 and insulin upon 2-deoxy-D$\left[1,2-{ }^{3} \mathrm{H}(\mathrm{N})\right]$ glucose uptake in streptozotocin-induced type 2 diabetic rats ( $n=8-16$; grey bars) and normal animals ( $n=5-14$; white bars). Values (mean \pm SEM) are expressed relative to the basal value found within the same rats. * $\mathrm{p}<0.05$.

Table I. Effect of inhibitors of kinase activity on basal and $10^{-9} \mathrm{M}$ Ex-4-stimulated glucose transport in rat skeletal muscle from normal rats.

\begin{tabular}{lcc}
\hline Inhibitor (M) & \multicolumn{2}{c}{$\%$ Basal value } \\
& $(425 \pm 25 \mathrm{pmol} / \mathrm{mg}$ protein per min $)$ \\
\cline { 2 - 3 } & Nil & Ex-4 \\
\hline Nil & $100 \pm 6$ & $129 \pm 5^{\mathrm{a}}$ \\
W $\left(10^{-6}\right)$ & $75 \pm 8^{\mathrm{a}}$ & $67 \pm 5^{\mathrm{a}}$ \\
PD $\left(2.5 \times 10^{-5}\right)$ & $72 \pm 10^{\mathrm{a}}$ & $66 \pm 9^{\mathrm{a}}$ \\
RAP $\left(10^{-7}\right)$ & $82 \pm 10$ & $78 \pm 3^{\mathrm{a}}$ \\
H-7 $\left(10^{-4}\right)$ & $91 \pm 12$ & $83 \pm 7$ \\
\hline
\end{tabular}

${ }^{\mathrm{a}} \mathrm{p}<0.05$ vs basal value. W, wortmannin; PD, PD98059; RAP, rapamycin.

Glycogen synthase a activity. The net basal glycogen synthase $a$ activity in type 2 diabetic rat muscle $(4.45 \pm 0.45 \mathrm{U} / \mathrm{g}$, $\mathrm{n}=10)$ was slightly higher $(\mathrm{p}=0.032)$ than that in the normal control animals $(3.27 \pm 0.30 \mathrm{U} / \mathrm{g}, \mathrm{n}=19)$. No effect could be detected in the presence of $10^{-9} \mathrm{M} \mathrm{Ex}-4$, as opposed to an effect previously observed in normal rat skeletal muscle, where a small but clear increment was measured (7).

Glycolysis and glucose oxidation. The basal value of pyruvate produced by type 2 diabetic rat muscle $(3.36 \pm 0.71 \mathrm{nmol} / \mathrm{mg} / \mathrm{min}$, $\mathrm{n}=9$ ) was significantly higher $(\mathrm{p}=0.019)$ than that observed in muscle samples from normal rats $(1.05 \pm 0.21 \mathrm{nmol} / \mathrm{mg} / \mathrm{min}$, $\mathrm{n}=10$ ). In normal rats, $10^{-9} \mathrm{M} \mathrm{Ex}-4$ caused an increase in pyruvate production $(230 \pm 43 \%$ basal, $n=7, p<0.05$ vs basal), while it failed to affect pyruvate production in the muscle of type 2 diabetic rats $(108 \pm 24 \%$ basal, $n=9)$.

The basal value of $\mathrm{CO}_{2}$ produced by type 2 diabetic rat muscle $(5.32 \pm 0.53 \mathrm{nmol} / \mathrm{mg} / \mathrm{min}, \mathrm{n}=10)$, although somewhat 
lower, was not significantly different from that produced by muscle samples from normal rats $(6.40 \pm 0.43 \mathrm{nmol} / \mathrm{mg} / \mathrm{min}$, $\mathrm{n}=14$ ). In the normal rats included in the present study, $10^{-9} \mathrm{M}$ Ex-4 induced a moderate increase of the basal value $(121 \pm 4 \%$ control, $n=14, p<0.001)$ as previously observed (7), while it apparently failed to affect $\mathrm{CO}_{2}$ in the muscle of the type 2 diabetic group $(118 \pm 8 \%$ basal, $n=10, p=0.11)$.

\section{Discussion}

This study aimed to identify the action of exendins upon glucose transport in normal rat skeletal muscle, and to further investigate their characteristics in a type 2 diabetic state. We had previously observed in normal rats that Ex-4, but not Ex-9, stimulated muscle glycogen synthesis, through an increase in the activity of glycogen synthase $a$, and also glucose oxidation and utilization, as did GLP-1 (7). In the present study, we found that, in normal rat skeletal muscle, Ex-4 enhanced glucose uptake, with an equal and higher potency, respectively, than that previously reported for insulin and GLP-1 (28). We also found that for this stimulatory effect, Ex-4 perhaps acted, at least in part, through the same muscle GLP-1 receptor, and also, that the peptide required an increase in the activity of some of the same kinases (PI3K/PKB, p70s6k and MAPKs) shown to be involved, each to a higher or lower extent, in GLP-1 and insulin action (28). However, in the case of Ex-4, and at variance with GLP-1, the enzymes studied in the present report seem to be essential in increasing basal glucose uptake. Ex-9, an antagonist of GLP-1 receptors in certain cell systems and also of some of the effects of GLP-1 and Ex-4 (7), although also augmenting the activity of the same kinases as those augmented by Ex-4, except that of $\mathrm{PKB}$, failed to modify the glucose transport basal value in normal rat skeletal muscle. This last is at variance with its characteristics in human muscle, tissue and cells, in which, perhaps due to species differences, Ex-9 shows GLP-1-like actions upon parameters involved in glucose metabolism $(6,8,15,16)$.

The muscle of the T2D rats studied in the present report showed a lower than normal basal rate of glucose uptake, and a higher glycogen synthase $a$ activity, the former being in accordance with a reported reduced Glut-4 expression in the muscle of the same diabetic model (25). We also detected a lower basal ${ }^{14} \mathrm{CO}_{2}$ production and a higher pyruvate release, which could be a consequence of a deleterious entrance of pyruvate into the tricarboxilic acid cycle, due to a higher concentration of circulating free fatty acids (29); in relation to this, a higher basal rate of lipolysis was reported in isolated rat adipocytes from this type 2 diabetic model (5). This unbalanced lipid/glucose rate could explain why Ex-4 failed to affect glycogen synthase $a$ activity or glucose oxidation and utilization values, at variance with GLP-1, for which a stimulatory action in muscle and other extrapancreatic tissues from type 2 diabetic rats, has been reported (17). However, we did not detect any in vitro modification of GLP-1 or Ex-4 (present data) upon the basal glucose uptake value, despite the fact that prolonged treatment with GLP-1 of streptozotocin-induced type 2 diabetic rats increased the reduced muscle Glut-4 gene expression up to normal levels (25). In addition, the basal activity of both PI3K and PKB appeared lower than normal, while that of p70s6k and MAPKs was clearly higher. Together with this, GLP-1 failed to affect the basal activity of any of the kinases studied, while the muscle tissue maintained the PI3K, p70s6k and MAPK response capability to Ex-4, but not PKB, suggesting a major role for this enzyme in Ex-4 stimulatory effect upon glucose transport in muscle.

As it has been shown that continuous infusion of GLP-1 normalizes reduced diabetic muscle Glut-4 expression, the fact that the demonstrated antidiabetic action of both GLP-1 and Ex-4 was not reflected in their in vitro stimulatory effect upon glucose transport in the diabetic rat, does not exclude the possibility that, in prolonged treatment, these peptides could improve glucose uptake.

\section{Acknowledgements}

This study was supported by grants from the Institute of Health Carlos III (PI 060076 and RD 0600150004), Spain. LA and PT-E are, and NG, VS and ED were, Research Fellows from the Fundación Conchita Rábago de Jiménez Díaz. We thank Estrella Martín-Crespo for excellent technical assistance and Mark Davis for proofreading the manuscript.

\section{References}

1. Mentlein R: Dipeptidyl-peptidase IV (CD26)-rode in the inactivation of regulatory peptides. Regul Pept 85: 9-24, 1999.

2. Doyle ME and Egan JM: Glucagon-like peptide-1. Recent Prog Horm Res 56: 377-399, 2001.

3. Nielsen LL, Young AA and Parkes DG: Pharmacology of exenatide (synthetic exedin-4): a potential therapeutic for improved glycemic control of type 2 diabetes. Regul Pept 117: 77-88, 2004.

4. Cancelas J, Villanueva-Peñacarrillo ML, Valverde I and Malaisse WJ: Synergistic insulinotropic effects of succinic acid dimethyl ester and exendin-4 in anaesthetized rats. Int J Mol Med 8: 269-271, 2001.

5. Sancho V, Trigo MV, González N, Valverde I, Malaisse WJ and Villanueva-Peñacarrillo ML: Effects of GLP-1 and exendins on kinase activity, 2-deoxy-D-glucose transport, lipolysis and lipogenesis in adipocytes from normal and streptozotocininduced type 2 diabetic rats. J Mol Endocrinol 35: 27-38, 2005.

6. González N, Acitores A, Sancho V, Valverde I and Villanueva-Peñacarrillo ML: Effect of GLP-1 on glucose transport and its cell signalling in human myocytes. Regul Pept 126: 203-211, 2005.

7. Alcántara AI, Morales M, Delgado E, López-Delgado MI, Clemente F, Luque MA, Malaisse WJ, Valverde I and Villanueva-Peñacarrillo ML: Exendin-4 agonist and exendin(939)amide antagonist of the GLP-1(7-36)amide effects in liver and muscle. Arch Biochem Biophys 341: 1-7, 1997.

8. Luque MA, González N, Márquez L, Acitores A, Redondo A, Morales M, Valverde I and Villanueva-Peñacarrillo ML: GLP-1 and glucose metabolism in human myocytes. J Endocrinol 173: 465-473, 2002.

9. Valverde I, Mérida E, Delgado E, Trapote MA and Villanueva-Peñacarrillo ML: Presence and characterization of glucagon-like peptide-1(7-36)amide receptors in solubilized membranes of rat adipose tissue. Endocrinology 132: 75-79, 1993.

10. Villanueva-Peñacarrillo ML, Delgado E, Trapote MA, Alcántara A, Clemente F, Luque MA, Perea A and Valverde I: Glucagon-like peptide-1 binding to rat hepatic membranes. J Endocrinol 146: 183-189, 1995.

11. Delgado E, Luque MA, Alcántara A, Trapote MA, Clemente F, Galera C, Valverde I and Villanueva-Peñacarrillo ML: Glucagon-like peptide-1 binding to rat skeletal muscle. Peptides 16: $225-229,1995$.

12. Thorens B, Porret A, Bühler L, Deng SP, Morel P and Widmann C: Cloning and functional expression of the human islet GLP-1 receptor: demonstration that exendin-4 is an agonist and exendin(939) an antagonist of the receptor. Diabetes 42: 1678-1682, 1993 
13. Göke R, Fehmann HC, Linn T, Schmidt H, Krause M, Eng J and Göke B: Exendin-4 is a high potency agonist and truncated exendin-(9-39)-amide an antagonist at the glucagon-like peptide 1-(7-36)-amide receptor of insulin-secreting beta-cells. J Biol Chem 268: 19650-19655, 1993.

14. Cancelas J, Villanueva-Peñacarrillo ML, Valverde I and Malaisse WJ: Suppression by exendin(9-39)amide of glucagonlike peptide 1 insulinotropic action in rats infused with the dimethyl ester of succinic acid. Endocrine 15: 283-285, 2001.

15. Montrose-Rafizadeh C, Yang H, Wang Y, Roth J, Montrose MH and Adams LG: Novel signal transduction and peptide specificity of glucagon-like peptide receptor in 3T3-L1 adipocytes. J Cell Physiol 172: 275-283, 1997.

16. Yang H, Egan JM, Wang Y, Moyes D, Roth J, Montrose MH and Montrose-Rafizadeh C: GLP-1 action in L6 myotubes is via a receptor different from the pancreatic GLP-1 receptor. Am J Physiol 275: C675-C683, 1998.

17. Morales M, López-Delgado MI, Alcántara A, Luque MA, Clemente F, Márquez L, Puente J, Viñambres C, Malaisse WJ, Villanueva-Peñacarrillo ML and Valverde I: Preserved GLP-1 effects upon glycogen synthase a activity and glucose metabolism in isolated hepatocytes and skeletal muscle from diabetic rats. Diabetes 46: 1264-1269, 1997.

18. Portha B, Picon L and Rosselin G: Chemical diabetes in the adult rat as the spontaneous evolution of neonatal diabetes. Diabetologia 17: 371-377, 1979

19. Vicent D, Villanueva-Peñacarrillo ML, Valverde I and Malaisse WJ: Impaired in vivo insulin secretion in response to non-glucidic secretagogues in adult rats after neonatal streptozotocin. Acta Diabetol 31: 133-137, 1994.

20. Villanueva-Peñacarrillo ML, Alcántara A, Clemente F, Delgado E and Valverde I: Potent glycogenic effect of GLP-1 (7-36) amide in rat skeletal muscle. Diabetologia 37: 1163-1166, 1994.

21. Bradford MM: A rapid and sensitive method for the quantization of microgram quantities of protein utilizing the principle of protein dye binding. Anal Biochem 72: 248-254, 1976.
22. Dohm GL, Tapscott EB, Pories WJ, Dabbs DJ, Flickinger EG, Meelheim TF, Atkinson SM, Elton CW and Caro JF: An in vitro human muscle preparation suitable for metabolic studies. J Clin Invest 82: 486-494, 1988.

23. Arnold TP, Stadaert ML, Hernandez H, Watson J, Mischak MG, Kazanietz MG, Zhao L, Cooper DR and Farese RV: Effects of insulin and phorbol esters on MARCKS (myristoylated alaninerich C-kinase substrate) phosphorylation (and other parameters of protein kinase $\mathrm{C}$ activation) in rat adipocytes, rat soleus muscle and BC3H-1 myocytes. Biochem J 295: 155-164, 1993.

24. Laemmli UK: Cleavage of structural proteins during the assembly of the head of bacteriophage T4. Nature 227: 680-685, 1970.

25. Villanueva-Peñacarrillo ML, Puente J, Redondo A, Clemente F and Valverde I: Effect of GLP-1 treatment on GLUT2 and GLUT4 expression in NIDDM and IDDM rats. Endocrine 15: 241-248, 2001

26. Phung TL, Roncone A, De Mesy Jensen KL, Sparks CE and Sparks JD: Phosphoinositide 3-Kinase activity is necessary for insulin-dependent inhibition of apolipoprotein B secretion by rat hepatocytes and localizes to the endoplasmic reticulum. J Biol Chem 272: 30693-30702, 1997.

27. Giroix MH, Sener A, Pipeelers DG and Malaisse WJ: Hexose metabolism in pancreatic islets. Inhibition of hexokinase. Biochem J 223: 447-453, 1984.

28. Acitores A, González N, Sancho V, Arnés L, Valverde I, Malaisse WJ and Villanueva-Peñacarrillo ML: Participation of protein kinases in the stimulant action of GLP-1 upon 2-deoxiD-glucose uptake by normal rat skeletal muscle. Horm Metab Res 37: 275-280, 2005.

29. Pari L and Ashokkumar N: Effect of N-benzoyl-d-phenylalanine on lipid profile in liver of neonatal streptozotocin diabetic rats Fundam Clin Pharmacol 19: 563-568, 2005. 